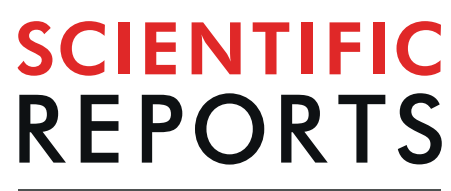

\title{
Horizontal and vertical movements of humpback whales inform the use of critical pelagic habitats in the western South Pacific
}

\begin{abstract}
Solène Derville ${ }^{1,2,3,4^{*}}$, Leigh G. Torres ${ }^{4}$, Alexandre N. Zerbini ${ }^{5}$, Marc Oremus ${ }^{6}$ \& Claire Garrigue ${ }^{1,2}$
Humpback whales (Megaptera novaeangliae) are known for their nearshore distribution during the breeding season, but their pelagic habitat use patterns remain mostly unexplored. From 2016 to 2018, 18 humpback whales were equipped with depth-recording satellite tags (SPLASH10) to shed light on environmental and social drivers of seamount association around New Caledonia in the western South Pacific. Movement paths were spatially structured around shallow seamounts $(<200 \mathrm{~m})$. Indeed, two males stopped over the Lord Howe seamount chain during the first-ever recorded longitudinal transit between New Caledonia and the east coast of Australia. Residence time significantly increased with proximity to shallow seamounts, while dive depth increased in the vicinity of seafloor ridges. Most of the 7,986 recorded dives occurred above $80 \mathrm{~m}(88.5 \%)$, but deep dives $(>80 \mathrm{~m}, \max 616 \mathrm{~m}$ ) were also recorded (11.5\%), including by maternal females. Deep dives often occurred in series and were characterized by U-shapes suggesting high energy expenditure. This study provides new insights into the formerly overlooked use of pelagic habitats by humpback whales during the breeding season. Given increasing anthropogenic threats on deep sea habitats worldwide, this work has implications for the conservation of vulnerable marine ecosystems.
\end{abstract}

Seamounts are recognized as important pelagic ecosystems and a major biome in the open ocean ${ }^{1}$. Defined as isolated topographic elevations with summit depths at least $100 \mathrm{~m}$ above the seafloor ${ }^{2}$, seamounts affect ocean circulation and mixing, leading to nutrient upwelling, and stimulated primary production ${ }^{3}$. In the tropics, where pelagic waters are generally nutrient depleted, seamounts can form an "oasis of productivity", which trigger trophic cascades attracting marine megafauna ${ }^{4-6}$. Hence, pelagic predators such as billfish, pinnipeds, seabirds, sharks and tuna have shown attraction to relatively shallow seamounts $(<1000 \mathrm{~m} \mathrm{depth})^{1}$. Toothed whales (e.g., sperm whales, beaked whales, dolphins) are known to associate with seamounts ${ }^{6-8}$, presumably finding enhanced feeding opportunities over these seabed features. In contrast, seamount use by baleen whales has rarely been described ${ }^{9}$.

Humpback whales (Megaptera novaeangliae) were recently discovered to visit seamounts during the breeding season and spring migration period occurring in tropical and subtropical latitudes ${ }^{10-13}$. Humpback whales seasonally migrate from the polar feeding grounds where they spend the summer, to the tropical breeding grounds where they mate and give birth during the winter. While they must spend extended periods of time in the open ocean, their habitat use patterns have primarily been studied nearshore ${ }^{14-21}$. Only in the last decade has satellite telemetry provided the means to monitor humpback whale at the scale of their extensive movements. In the western South Pacific, humpback whales were found to visit shallow seamounts in the late breeding season ${ }^{11}$. The purpose of these seamount stop-overs was hypothesized to be related to breeding activities, resting, use as navigational landmarks, or supplemental feeding ${ }^{11}$.

${ }^{1}$ UMR ENTROPIE, IRD, 101 promenade Roger Laroque, 98848, Nouméa, New Caledonia. 2Operation Cétacés, BP12827, 98802, Nouméa, New Caledonia. ${ }^{3}$ Sorbonne Universités, UPMC Univ Paris 6, IFD-ED129, 4 Place Jussieu, Paris, 75252, France. ${ }^{4}$ Geospatial Ecology of Marine Megafauna Lab, Marine Mammal Institute, Department of Fisheries and Wildlife, Oregon State University, 2030 SE Marine Science Drive, Newport, 97365, OR, USA. ${ }^{5}$ Marine Mammal Laboratory, Alaska Fisheries Science Center, 2725 Montlake Blvd E, Seattle, 98112, WA, USA. ${ }^{6}$ WWF France, Parc Forestier Michel Corbasson, BP692, 98845, Nouméa, New Caledonia. *email: s.derville@live.fr 


\begin{tabular}{|c|c|c|c|c|c|c|c|c|c|c|c|c|c|}
\hline \multirow[b]{2}{*}{ Year } & \multirow[b]{2}{*}{ ID } & \multirow[b]{2}{*}{$\begin{array}{l}\text { Sex/ } \\
\text { Status }\end{array}$} & \multirow[b]{2}{*}{$\begin{array}{l}\text { Group } \\
\text { type }\end{array}$} & \multirow[b]{2}{*}{ Locality } & \multirow[b]{2}{*}{ Start } & \multirow[b]{2}{*}{$\begin{array}{l}\text { Tag } \\
\text { duration } \\
\text { (days) }\end{array}$} & \multirow[b]{2}{*}{$\begin{array}{l}\text { Date leaving } \\
\text { the breeding } \\
\text { region }\end{array}$} & \multicolumn{6}{|c|}{ Within Breeding Region } \\
\hline & & & & & & & & $\begin{array}{l}\text { Tag } \\
\text { duration } \\
\text { (days) }\end{array}$ & $\begin{array}{l}\text { Minimum } \\
\text { total distance } \\
(\mathbf{k m})\end{array}$ & $\begin{array}{l}\text { \# raw } \\
\text { positions }\end{array}$ & $\begin{array}{l}\text { \# filtered } \\
\text { positions }\end{array}$ & $\begin{array}{l}\text { \# dives } \\
\text { recorded }\end{array}$ & $\begin{array}{l}\text { Dive } \\
\text { profiles } \\
\text { recorded } \\
\text { (hrs) }\end{array}$ \\
\hline \multirow{4}{*}{2016} & 154182 & $\mathrm{~F} / \mathrm{c}$ & MCE & $\mathrm{O}$ & $23 / 09 / 2016$ & 9.8 & - & 9.8 & 809 & 56 & 49 & 165 & 2 \\
\hline & 154183 & $\mathrm{~F}$ & $\mathrm{P}$ & $\mathrm{O}$ & $24 / 09 / 2016$ & 37 & $07 / 10 / 2016$ & 13.9 & 971 & 133 & 126 & 736 & 5 \\
\hline & 154184 & $\mathrm{~F} / \mathrm{c}$ & MCE & $\mathrm{O}$ & $23 / 09 / 2016$ & 15.2 & $30 / 09 / 2016$ & 7.7 & 571 & 32 & 30 & 80 & 3 \\
\hline & 154187 & $\mathrm{M}$ & MCR & $\mathrm{O}$ & $24 / 09 / 2016$ & 25.8 & $02 / 10 / 2016$ & 8.8 & 1041 & 42 & 33 & 25 & 0 \\
\hline \multirow{8}{*}{2017} & 34215 & $\mathrm{~F}$ & G3 & $\mathrm{A}$ & $24 / 07 / 2017$ & 125.3 & 09/08/2017 & 17.1 & 1194 & 123 & 106 & 184 & 7 \\
\hline & 154185 & $\mathrm{M}$ & G3 & A & $24 / 07 / 2017$ & 29 & - & 29 & 3429 & 242 & 206 & 975 & 36 \\
\hline & 34222 & $\mathrm{~F} / \mathrm{c}$ & MC & $\mathrm{CB}$ & $22 / 08 / 2017$ & 33.8 & - & 33.8 & 1907 & 203 & 187 & 555 & 18 \\
\hline & 34223 & - & $\mathrm{P}$ & $\mathrm{CB}$ & $17 / 08 / 2017$ & 6 & - & 6 & 390 & 42 & 35 & 110 & 5 \\
\hline & 34226 & $\mathrm{~F}$ & $\mathrm{~S}$ & $\mathrm{CB}$ & $22 / 08 / 2017$ & 46.7 & $21 / 09 / 2017$ & 30.5 & 2705 & 206 & 169 & 465 & 5 \\
\hline & 34227 & $\mathrm{~F} / \mathrm{c}$ & $\mathrm{MC}$ & $\mathrm{CB}$ & $18 / 08 / 2017$ & 70.5 & - & 70.5 & 4858 & 450 & 386 & 1188 & 27 \\
\hline & 34228 & $\mathrm{~F} / \mathrm{c}$ & MC & $\mathrm{CB}$ & $20 / 08 / 2017$ & 4.8 & - & 4.8 & 279 & 25 & 24 & 100 & 6 \\
\hline & 34221 & $\mathrm{~F}$ & $\mathrm{P}$ & $\mathrm{CB}$ & $12 / 08 / 2017$ & 5.8 & - & 5.8 & 496 & 5 & 6 & 25 & 0 \\
\hline \multirow{6}{*}{2018} & 34350 & $\mathrm{~F}$ & $\mathrm{C}$ & $\mathrm{A}$ & $17 / 07 / 2018$ & 32.9 & $24 / 08 / 2018$ & 19.9 & 1552 & 192 & 157 & 730 & 18 \\
\hline & 34354 & M & $\mathrm{P}$ & A & $21 / 07 / 2018$ & 45 & $12 / 08 / 2018$ & 32.5 & 3915 & 173 & 87 & 205 & 6 \\
\hline & 57535 & M & G3 & A & $17 / 07 / 2018$ & 8.8 & - & 8.8 & 500 & 94 & 81 & 249 & 7 \\
\hline & 57536 & $M$ & G4 & $\mathrm{A}$ & $21 / 07 / 2018$ & 21 & - & 21 & 1519 & 235 & 193 & 718 & 25 \\
\hline & 57537 & M & $\mathrm{C}$ & $\mathrm{A}$ & $21 / 07 / 2018$ & 10.8 & - & 10.8 & 617 & 154 & 131 & 715 & 24 \\
\hline & 57538 & M & G3 & $\mathrm{A}$ & $21 / 07 / 2018$ & 54.7 & $21 / 08 / 2018$ & 32.1 & 2618 & 344 & 277 & 761 & 32 \\
\hline
\end{tabular}

Table 1. Summary of satellite tracking for the 18 humpback whales tagged with SPLASH10 tags (Wildlife Computers) in New Caledonia. \#Stands for "number of". The minimum total distance $(\mathrm{km})$ is the along-thepath distance calculated from the CRW-interpolated tracks. Sex/Status: $F=$ Female, F/c $=$ Female with a calf, $\mathrm{M}=$ Male. Group type at the time of tagging: $\mathrm{MC}=$ Mother-calf, $\mathrm{MCE}=$ Mother calf escort, $\mathrm{C}=$ Competitive groups, $\mathrm{G} 3=$ Group of three adults, $\mathrm{G} 4=$ Group of four adults, $\mathrm{P}=\mathrm{Pair}, \mathrm{S}=$ Singleton. Locality: $\mathrm{O}=$ Orne bank, $\mathrm{A}=$ Antigonia seamount, $\mathrm{CB}=$ Chesterfield-Bellona archipelago. Date leaving the breeding region (see boundaries in Fig. 1a) is annotated "-" when the tag stopped emitting before the whale left the breeding region.

In the western South Pacific, humpback whales inhabit a primarily pelagic environment, spread with islands, reefs and seamounts ${ }^{22}$. As a result, breeding grounds are structured into separate populations and sub-populations with varying degrees of connectivity ${ }^{23-27}$. The endangered Oceania population of humpback whales ${ }^{23}$ includes the sub-population wintering off New Caledonia (and labelled by the International Whaling Commission as sub-stock E2 ${ }^{28}$ ), which occupies the most western region of the South Pacific ${ }^{29}$. This region is neighboured by the East Australian coast where sub-stock E1 $1^{29,30}$ migrates. Hence, humpback whales of New Caledonia and Australia are separated by the Coral Sea, a vast pelagic space stretching over more than $1,500 \mathrm{~km}$ covered with seamount chains and ridges, where marine megafauna distribution is poorly understood.

Pelagic seamounts may form crucial, yet formerly overlooked habitats for humpback whales to congregate and aid in movement across vast distances in Oceania ${ }^{11}$. Moreover, understanding the role played by seamounts in the distribution and movements of humpback whales in the open ocean is a prerequisite to effective management at the scale of giant marine protected areas (MPA) such as the recently created "Natural Park of the Coral Sea". Movement and dive tracking of humpback whales in breeding areas has to-date only been conducted during short periods $\mathrm{s}^{31-35}$ or too late in the season ${ }^{11,36-41}$, providing data that lacks the ability to capture pelagic behaviours within wintering latitudes. Here, integrated, implantable satellite tags were deployed on humpback whales in New Caledonia offshore waters to record horizontal and vertical movements over long durations (weeks to months) in open waters during the breeding season and early migration stages. Humpback whale movements and diving are analysed in relation to seamounts to understand their unique association with these ecologically important pelagic features.

\section{Results}

Localized and regional movements. Tagged whales included 7 males, 10 females and one individual of unknown sex. Five females were with a calf at the time of tagging, which were assumed to stay with their mother during the tracking duration. Whales were tracked for an average of 32.4 days ( \pm s.d. 29.9), including an average of 20.2 days ( \pm s.d. 16.3, Table 1 ) in the predefined breeding study region (Fig. 1a). They showed both localized (100 to $200 \mathrm{~km}$ wide) and regional movements ( $>1500 \mathrm{~km}$ wide). Once they left the breeding study region, whales were further tracked over their southward migration for an average of 12.3 days ( $\max =108.2$ days).

Humpback whales tagged in the seamounts and banks south of New Caledonia displayed localized movements between coastal and offshore shallow waters separated by 100 to $150 \mathrm{~km}$ (Fig. 1b). Among the 12 whales tagged in Orne bank and Antigonia seamount, three visited the coastal waters of the South Lagoon and four visited waters around the Isle of Pines. Connectivity between Orne bank and Antigonia was also revealed, as three whales out of the 12 tagged in this area visited both sites separated by $155 \mathrm{~km}$ (\#154182, \#57536, and \#34350). 


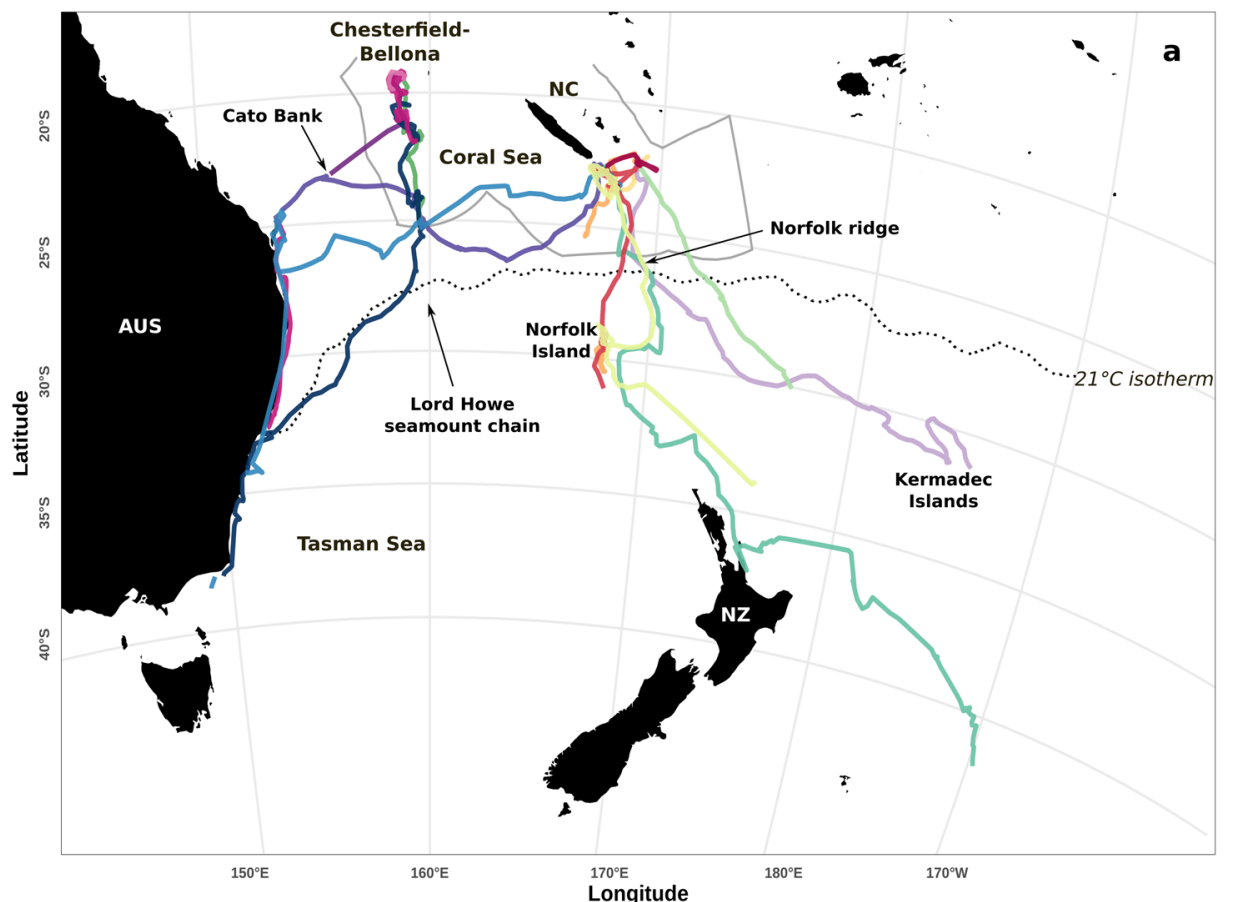

Tag ID

- 2016-154182

- 2016-154183

- 2016-154184

- 2016-154187

- 2017-154185

- 2017-34215

- 2017-34221

- 2017-34222

- 2017-34223

- $2017-34226$

- 2017-34227

- 2017-34228

- 2018-34350

- 2018-34354

- 2018-57535

- 2018-57536

- 2018-57537

2018-57538
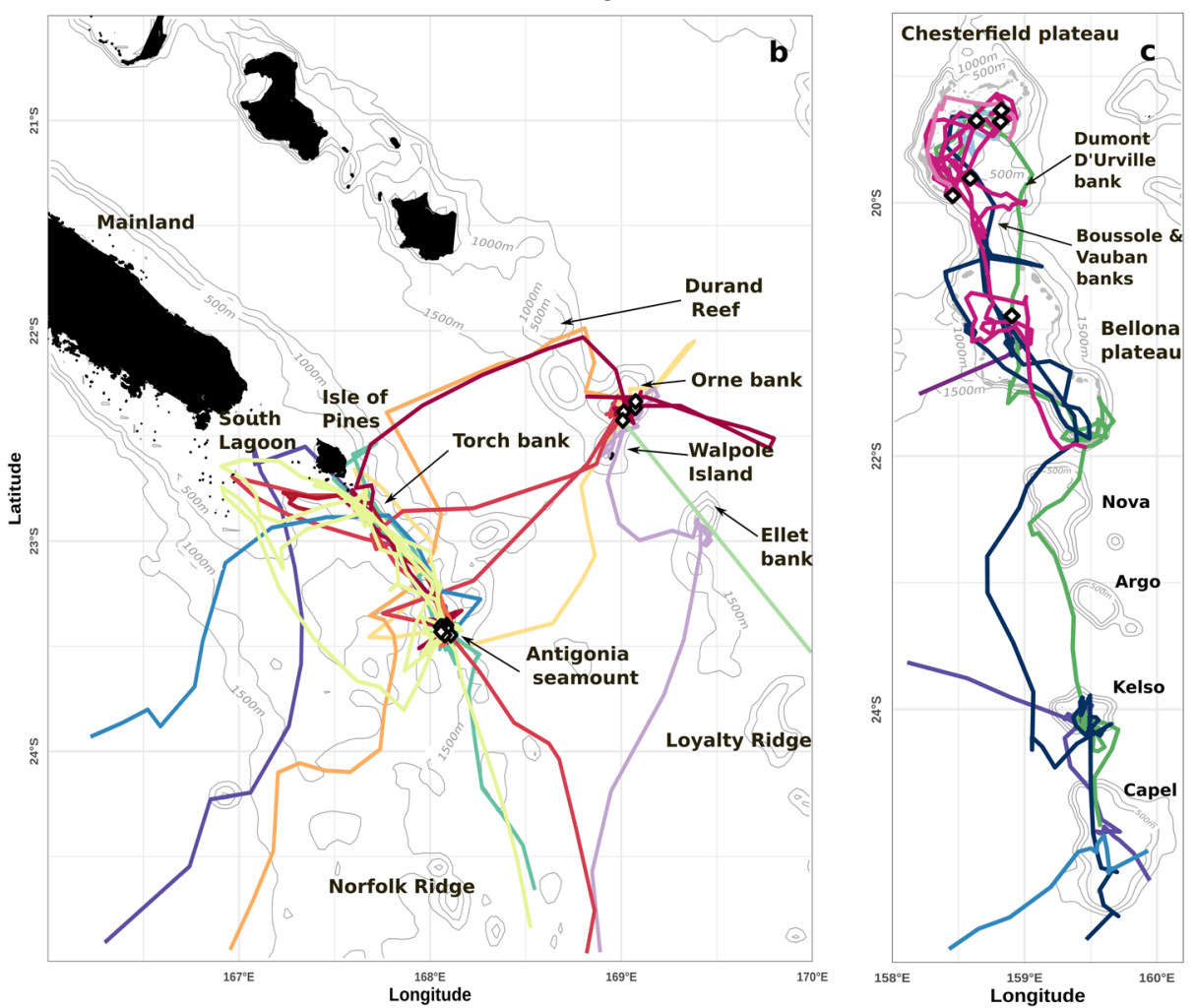

Figure 1. Satellite tracks recorded from 18 SPLASH10 tags deployed on humpback whales in New Caledonia. (a) Regional view (with southern borders of the Natural Park of the Coral Sea in grey) showing Australia (AUS), New Zealand (NZ) and New Caledonia (NC); (b) Zoom on Southeastern New Caledonia (Norfolk and Loyalty ridges); and (c) Zoom on the Chesterfield-Bellona coral reef complex and Lord Howe seamount chain. Grey lines represent $500 \mathrm{~m}$ isobaths up to $2000 \mathrm{~m}$ deep. Land is shown in black. The locations of tag deployments are shown with white diamond shapes. The breeding study region is demarcated by the $21^{\circ} \mathrm{C}$ isotherm shown with a dotted line in (a).

Similar localized movements were observed for whales tagged in the Chesterfield-Bellona coral reef complexes. They displayed localized movements within these shallow plateaus before initiating their southward migration (Fig. 1c). While they spent some significant time in the sheltered waters of the inner reefs (mean $=10.2$ days \pm s.d. 


\begin{tabular}{|c|c|c|c|c|c|c|c|c|c|c|}
\hline \multirow[b]{2}{*}{ year } & \multirow[b]{2}{*}{ ID } & \multirow{2}{*}{$\begin{array}{l}\text { Sex/ } \\
\text { Status }\end{array}$} & \multirow[b]{2}{*}{ Locality } & \multicolumn{3}{|c|}{ Dive depth (m) } & \multicolumn{3}{|c|}{ Dive duration (min) } & \multirow{2}{*}{$\begin{array}{l}\% \text { dive } \\
>80 \mathrm{~m}\end{array}$} \\
\hline & & & & mean & sd & $\max$ & mean & sd & $\max$ & \\
\hline \multirow{4}{*}{2016} & 154182 & $\mathrm{~F} / \mathrm{c}$ & $\mathrm{O}$ & 62.5 & 59.7 & 336 & 6.3 & 3.6 & 16.1 & 24.8 \\
\hline & 154183 & F & $\mathrm{O}$ & 47.8 & 52.5 & 288 & 4.8 & 3.5 & 16.4 & 13.9 \\
\hline & 154184 & $\mathrm{~F} / \mathrm{c}$ & $\mathrm{O}$ & 43.6 & 57.4 & 240 & 4.2 & 2.4 & 10.6 & 16.2 \\
\hline & 154187 & M & $\mathrm{O}$ & 29.2 & 21.2 & 92 & 6.6 & 3.4 & 13.1 & 4 \\
\hline \multirow{8}{*}{2017} & 34215 & $\mathrm{~F}$ & A & 44 & 45.1 & 344 & 6.5 & 4.6 & 22 & 11.4 \\
\hline & 154185 & $\mathrm{M}$ & A & 60 & 69.4 & 392 & 5.3 & 3.8 & 16.7 & 15.9 \\
\hline & 34222 & F/c & $\mathrm{CB}$ & 47.7 & 40.6 & 288 & 5.6 & 3.3 & 18.4 & 15 \\
\hline & 34223 & - & $\mathrm{CB}$ & 47.1 & 28 & 188 & 6 & 4.2 & 22.3 & 4.5 \\
\hline & 34226 & $\mathrm{~F}$ & $\mathrm{CB}$ & 50.1 & \begin{tabular}{|l|l|}
52.9 \\
\end{tabular} & 616 & \begin{tabular}{|l|}
6.9 \\
\end{tabular} & 4.7 & 22.1 & 10.5 \\
\hline & 34227 & F/c & CB & 27.4 & 14.7 & 192 & 4.7 & 3 & 24.3 & \begin{tabular}{|l|}
0.1 \\
\end{tabular} \\
\hline & 34228 & $\mathrm{~F} / \mathrm{c}$ & $\mathrm{CB}$ & 28.2 & \begin{tabular}{|l|l|}
16.7 \\
\end{tabular} & 74 & 6.6 & 3.1 & \begin{tabular}{|l|l|}
13.8 \\
\end{tabular} & 0 \\
\hline & 34221 & $\mathrm{~F}$ & СB & 55.5 & 60.6 & 220 & 11.5 & \begin{tabular}{|l|} 
\\
\end{tabular} & 23.7 & 12 \\
\hline \multirow{6}{*}{2018} & 34350 & F & $\mathrm{A}$ & 55.5 & \begin{tabular}{|l|l}
61.8 \\
\end{tabular} & 448 & \begin{tabular}{|l|l}
7.2 \\
\end{tabular} & 5.2 & 24.2 & \begin{tabular}{|l|l|}
20.1 \\
\end{tabular} \\
\hline & 34354 & $\mathrm{M}$ & $\mathrm{A}$ & 62.2 & 42.6 & 312 & \begin{tabular}{|l|}
6.9 \\
\end{tabular} & 4.9 & 23.2 & \begin{tabular}{|l|l|}
25.9 \\
\end{tabular} \\
\hline & 57535 & $\mathrm{M}$ & $\mathrm{A}$ & 38.6 & 34.5 & 296 & 4.4 & 2.9 & 12.2 & 7.2 \\
\hline & 57536 & M & A & 35.2 & \begin{tabular}{|l|l|}
30.4 \\
\end{tabular} & 376 & \begin{tabular}{|l|l|}
6.9 \\
\end{tabular} & 4.5 & 26.2 & 4.5 \\
\hline & 57537 & $\mathrm{M}$ & $\mathrm{A}$ & 38 & \begin{tabular}{|l|l|}
36.8 \\
\end{tabular} & 303 & 4.5 & 3.3 & 19 & \begin{tabular}{|l|}
4.8 \\
\end{tabular} \\
\hline & 57538 & M & A & 68.8 & 82 & 520 & 5.3 & 4.5 & 21.9 & 20.9 \\
\hline
\end{tabular}

Table 2. Summary of diving behavior recorded for the 18 humpback whales tagged with SPLASH10 tags (Wildlife Computers) in New Caledonia. Sex/Status: $\mathrm{F}=$ Female, F/c $=$ Female with a calf, $\mathrm{M}=$ Male. Locality: $\mathrm{O}=$ Orne bank, $\mathrm{A}=$ Antigonia seamount, $\mathrm{CB}=$ Chesterfield-Bellona archipelago. Diving behaviour is only considered within the predefined breeding region (see boundaries in Fig. 1a).

9.8 days), they also visited shallow offshore features such as the Dumont D’Urville, Vauban and Boussole banks located between the Chesterfield and the Bellona plateaus.

Humpback whales leaving the waters south of the New Caledonia mainland also performed extensive regional movements following two main trajectories. Six whales moved south and southeast: three passed by Norfolk Island, one passed by New Zealand and two moved in the direction of the Kermadec Islands. Two males moved west (\#154185 and \#34354), stopped over the seamounts of the Lord Howe chain (for 7 and 3 days, respectively) and finally reached the East Australian coast around $25^{\circ} \mathrm{S}$ (Fig. 1a). Whale \#154185 also stopped for 3 days around Cato Bank, an isolated bank with a small, emerged reef and islet located west of the Coral Sea.

In Chesterfield-Bellona, two females (\#34222 with a calf, and \#34226) could be tracked south of the coral reef complexes, and they both navigated through the Nova seamount, then spent time over the Kelso and Capel seamounts ( 10 days for \#34222 and 4 days for \#34226 over these two seamounts). Finally, three out of the six whales tagged in the Chesterfield-Bellona moved westward after leaving the Lord Howe chain. Two females (\#34227 with a calf, and \#34226) were tracked while migrating south along the East Australian coast in 2017, plus one male in 2018 (\#34354).

Diving behaviour in wintering latitudes. Dive depths in the breeding region were mostly concentrated above $80 \mathrm{~m}$ deep ( $88.5 \%$ of dives, Table 2$)$. A minority of dives occurred below $80 \mathrm{~m}$ (11.5\%). The maximum dive depth of $616 \mathrm{~m}$ was reached by female \#34226 east of the Bellona plateau in waters about 2,550 m deep. Deep dives below $80 \mathrm{~m}$ often occurred in series (Fig. 2), with 66\% of deep dives occurring in a series of multiple (range: 2-20) deep dives. Deep dives were performed by all categories of individuals (Table 2), including females with a calf $(\max$ depth $=336 \mathrm{~m})$.

On average males dove to $51.1 \mathrm{~m}$ ( \pm s.d. 59.2$)$, females without a calf dove to $50.7 \mathrm{~m}$ ( \pm s.d. 55.6$)$, and females with a calf dove to $36.2 \mathrm{~m}$ ( \pm s.d. 33.4). Sex and breeding status did not significantly influence dive depth (ANOVA with rank transformation: $\mathrm{n} . \mathrm{obs}=7,876$, n.groups $=17, \mathrm{df}=2, \mathrm{~F}=0.964, \mathrm{p}=0.405)$. Dive durations averaged $5.2 \mathrm{~min}( \pm$ s.d. 3.2$)$ for females with a calf, $5.5 \mathrm{~min}( \pm$ s.d. 4.1$)$ for males, and $6.3 \mathrm{~min}( \pm$ s.d. 4.7$)$ for females without a calf. Dive duration did not significantly differ between females, females with a calf, and males (ANOVA with rank transformation: $\mathrm{n} . \mathrm{obs}=7,876$, n.groups $=17, \mathrm{df}=2, \mathrm{~F}=0.978, \mathrm{p}=0.401$ ).

Dive depth and duration showed a positive non-linear correlation $(\mathrm{n}=7,984$, Spearman's rho $=0.50, \mathrm{p}=2.2 \mathrm{e}$ 16). Based on dive shape, duration and depth, two categories of dives could be distinguished (Fig. 3). Deep dives below $80 \mathrm{~m}$ showed intermediate duration ( $\operatorname{mean}=8.3 \mathrm{~min} \pm \mathrm{s} . \mathrm{d} .3 .3, \max =24.0 \mathrm{~min}$ ) and primarily composed of U-shaped dives (76\%). Shallow dives above $80 \mathrm{~m}$ and with long durations were primarily square-shaped (54\%). V-shapes were the least common (6.2\% of all dives), and were found both in deep and shallow dives.

Dive profiles were recorded during 226 hours, spread over 170 separate dive bouts, representing an average of 14.1 hours ( \pm s.d. 11.4) per individual. Among these dive profiles, 48 bouts representing 66 hours of recording contained at least one deep dive below $80 \mathrm{~m}$. In these profiles, series of deep dives were observed and time spent at depth was evaluated (Fig. 4). On average, whales spent $2.5 \mathrm{~min}( \pm$ s.d. $1.5, \max =7 \mathrm{~min})$ at maximum depth during deep dives recorded in the 48 profile bouts. Deep dives occurred in series of increasing depth in $44 \%$ of the dive profile bouts (Fig. 4), in series of decreasing depth in $8 \%$ of the bouts, and as stand-alone events in $21 \%$ of the 


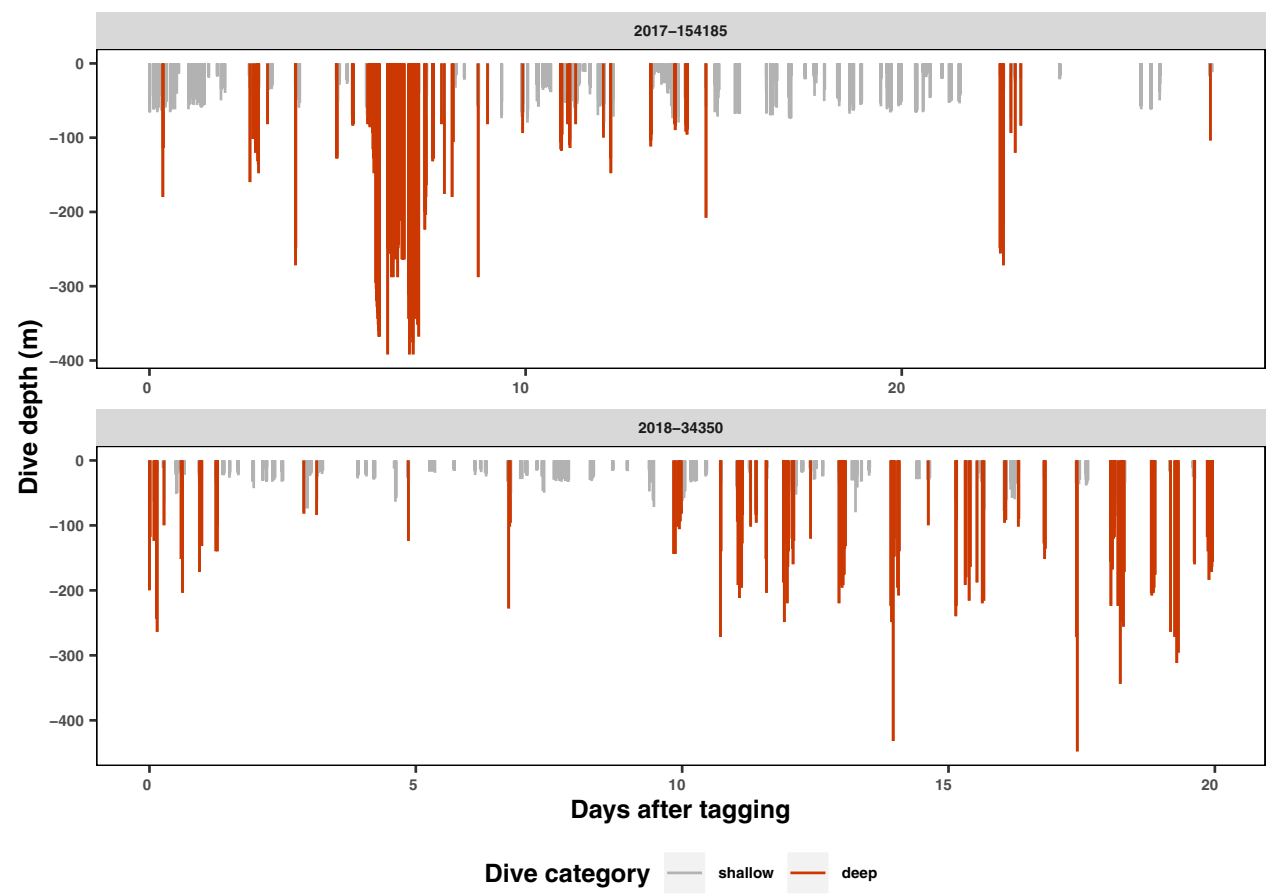

Figure 2. Dive depths through time for two whales tagged in New Caledonia (male \#154185 and female \#34350). The $\mathrm{x}$-axis represents time from deployment in days. Each vertical bar represents a single dive event. Dives deeper than $80 \mathrm{~m}$ are shown in red.

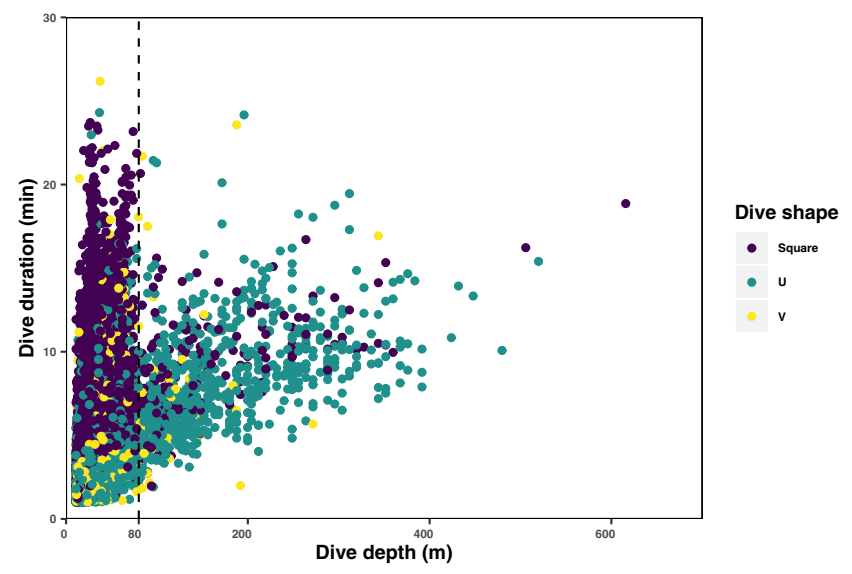

Figure 3. Relation between dive depth and duration for 18 whales tagged in New Caledonia ( $\mathrm{n}=7,986$ dives). The dashed line delineates dives deeper than 80 meters. Dive shape (Square, U and V) are represented by color.

bouts. For instance, the whale \#34215 dove in a series of increasingly deep dives, from about $80 \mathrm{~m}$ to more than $300 \mathrm{~m}$. Time spent at the bottom of the two deepest dives reached 5 minutes (Fig. 4).

Pelagic movements in relation to seamounts. Out of 18 tagged whales, 16 individuals had dive events recorded in pelagic habitats. Many of the deep dives were recorded when whales were in the vicinity of the Lord Howe seamount chain, the Norfolk Ridge and the Loyalty Ridge (Fig. 5, and Supplementary Fig. S1). Diel phase significantly affected dive depth in pelagic habitats, as shallower dives were recorded at night (ANOVA with rank transformation: .obs $=6,409$, n.groups $=16, \mathrm{df}=1, \mathrm{~F}=122.27, \mathrm{p}<0.0001$; Supplementary Figs. S2 and S3).

Distance to seamounts of all depths significantly affected mean residence time (Table 3 ). Indeed, residence time increased when whales were close to seamounts (Fig. 6a), and this pattern was stronger for seamounts shallower than $200 \mathrm{~m}$ (deviance explained $=17.7 \%$, Table 3 ). The mean maximum dive depth also appeared to be related to distance to seamounts although this relation was weak (Table 3). Distance to seamounts significantly affected dive depth when considering seamounts shallower than $500 \mathrm{~m}$ (deviance explained $=3.2 \%)$ and $200 \mathrm{~m}$ (deviance explained $=3.5 \%$ ), but not when all seamounts were included (deviance explained $=0.5 \%$ ). The average maximum dive depth was highest within $200 \mathrm{~km}$ of a shallow seamount $<200 \mathrm{~m}$ (Fig. 6b). 


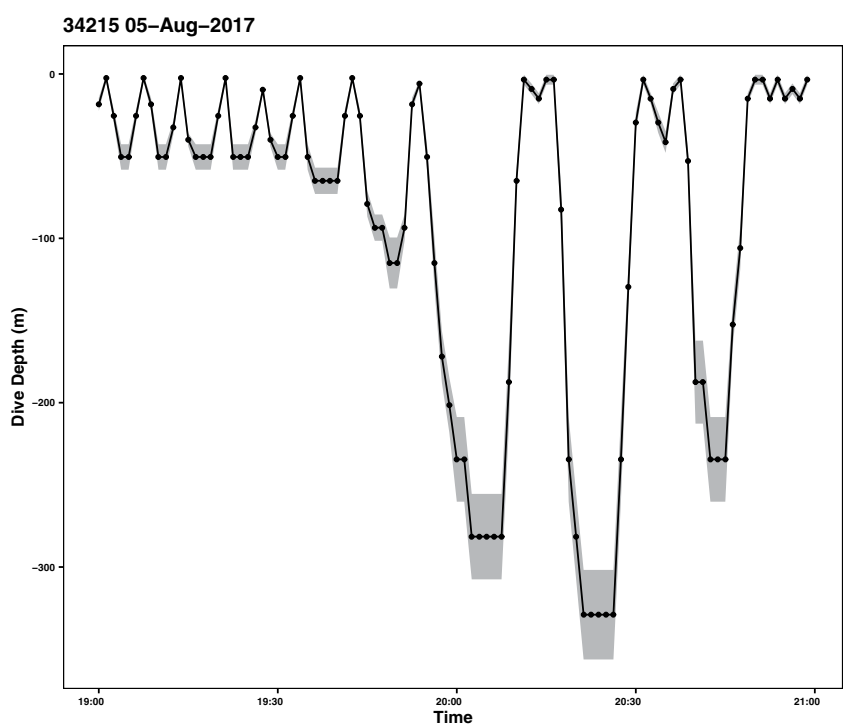

Figure 4. Example of a dive profile for the humpback whale \#34215 (female), recorded at a frequency of one measurement every 75 seconds on August $5^{\text {th }}, 2017$. The grey ribbon shows the uncertainty of the depth measurement.

\section{Discussion}

Using satellite tracking and dive recording, this study characterized vertical and horizontal movements of humpback whales in coastal and pelagic habitats of the Coral Sea during the breeding season. Tracking at a wide spatial scale allowed for a more comprehensive description of diving patterns and revealed a relatively high proportion of deep dives for adult whales of all social types, indicating unexpected energy expenditure, specifically around the Lord Howe seamount chain and the Norfolk ridge. A strong affinity for seamount habitats was further illustrated in horizontal movements. Finally, localized (100 to $200 \mathrm{~km}$ wide) and extensive regional movements $(>1500 \mathrm{~km}$ wide) were revealed and shed light on the spatially-structured mating system of humpback whales.

Most studies of humpback whale diving patterns have been conducted in feeding areas ${ }^{42-49}$. A few studies have targeted the breeding season, but only over short tracking durations, generally less than a day ${ }^{31-35}$. In this study, we recorded a dive of $616 \mathrm{~m}$, which appears to be the deepest dive ever recorded for an adult humpback whale, surpassing previously reported 'deepest dives' at $388 \mathrm{~m}$ (Antarctic Peninsula ${ }^{48}$ ), $392 \mathrm{~m}$ (West Greenland ${ }^{47}$ ) and $396 \mathrm{~m}\left(\right.$ Hawaii $\left.^{50}\right)$. Here, even mothers with a calf were found to dive as deep as $336 \mathrm{~m}$. Calves of a few months old have been observed swimming down to $250 \mathrm{~m}$ in the Western Antarctic Peninsula ${ }^{43}$, but it is unknown whether the calves followed their mother on deep dives in this study.

Deep dives often occurred in series, and were U-shaped, resulting in prolonged time spent at the bottom of each dive, thus indicating large energy expenditure ${ }^{44,48,49}$. Several hypotheses could explain why humpback whales of all social types perform these energy-consuming deep dives in breeding regions. First, a scouting hypothesis could suggest that whales dive deep to gain orientation information during navigation between breeding grounds. Turbulences resulting from seafloor relief could constitute important cues for whales to localize their suitable shallow habitats or migration pathways ${ }^{51}$. No information is currently available to describe the mechanisms by which oceanographic stimuli may be sensed by baleen whales, but ocean circulation is postulated to be among the main sensory modalities used by baleen whales to locate prey ${ }^{52}$ and navigate ${ }^{53}$ at meso $(10 \mathrm{~km})$ to large scales $(100 \mathrm{~km})$. Deep dives may therefore serve a sensory and navigational role ${ }^{54}$, especially as shallow seamounts are shown to be the most attractive for humpback whales. Second, a social hypothesis could suggest that humpback whales dive deep to listen/communicate with conspecifics, or as a result of intra-specific interactions during competition for mating. Indeed, humpback whales in competitive groups have been observed with Crittercams displaying competitive behaviour at depth, up to $298 \mathrm{~m}^{34}$. Interactions within competitive groups composed of a female and several males could therefore explain some of the deep dives that occurred in the vicinity of recognized breeding grounds (e.g. Orne bank, Antigonia seamounts) where such competitive activities take place ${ }^{55}$.

The third hypothesis is that of opportunistic feeding. The successive deep U-shaped dives observed on several occasions are analogous to foraging dives of humpback whales and other rorquals ${ }^{44,56}$. Indeed, deep foraging dives often include a greater number of feeding lunges than during surface feeding, resulting in more time at depth ${ }^{43,46}$. For instance, blue whales (Balaenoptera musculus) and fin whales (Balaenoptera physalus) dive deeper and longer when feeding ${ }^{57}$. Although humpback whales are generally expected to fast during the breeding season ${ }^{58,59}$, occasional feeding outside feeding grounds has been reported in a few locations: in Samana Bay, Dominican Republic $^{60}\left(19^{\circ} \mathrm{N}\right)$, off the coast of Brazil ${ }^{61,62}\left(19.5^{\circ} \mathrm{S}\right)$, in the Gulf of California ${ }^{63}\left(24.5^{\circ} \mathrm{N}\right)$, off the coast of Eden, east Australia ${ }^{36}\left(37^{\circ} \mathrm{S}\right)$ and in the New Caledonia South Lagoon $\left(22^{\circ} \mathrm{S}\right.$, C. Garrigue pers. obs., a humpback whale was feeding at the surface on a fish school). Satellite tracking of humpback whales leaving their breeding grounds has also revealed Area Restricted Search interpreted as opportunistic feeding: off the Paracas coast, Peru ${ }^{40}\left(15^{\circ} \mathrm{S}\right)$, in Magdalena bay, Baja California ${ }^{64}\left(25^{\circ} \mathrm{N}\right)$, over the Kermit-Roosevelt seamount, north of Hawaii ${ }^{39}\left(39^{\circ} \mathrm{N}\right)$, and 

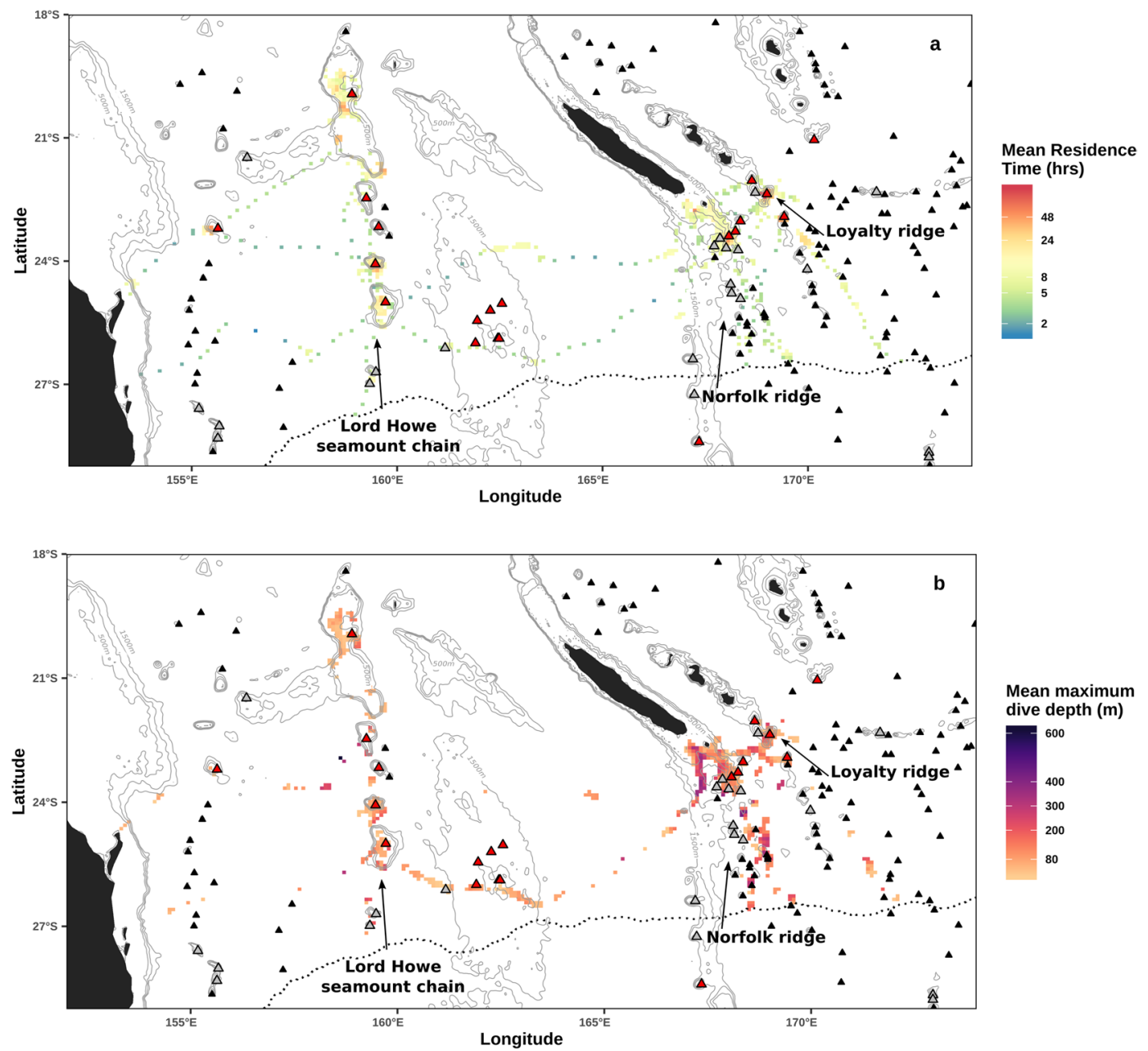

Mean maximum dive depth $(m)$

Figure 5. Pelagic horizontal and vertical movements averaged per individual over a grid of $10 \mathrm{~km}$ resolution. (a) Mean Residence Time (hrs) estimated from the CRW-interpolated tracks of 18 humpback whales. (b) Maximum dive depths (m) averaged for 16 humpback whales. Seamounts with varying depths are represented with triangles (Allain et al. 2008): shallower than $200 \mathrm{~m}$ (red), between 200 and $500 \mathrm{~m}$ (grey) and deeper than $500 \mathrm{~m}$ (black). Grey lines represent $500 \mathrm{~m}$ isobaths up to $2000 \mathrm{~m}$ deep. Land is shown in black. The breeding study region is demarcated by the $21^{\circ} \mathrm{C}$ isotherm shown with a dotted line.

\begin{tabular}{|l|l|l|l|l|l|l|}
\hline & \multicolumn{2}{|l|}{$\begin{array}{l}\text { Distance to seamounts } \\
<\mathbf{2 0 0} \mathbf{~ m}\end{array}$} & \multicolumn{2}{l|}{$\begin{array}{l}\text { Distance to seamounts } \\
<\mathbf{5 0 0} \mathbf{~ m}\end{array}$} & \multicolumn{2}{l|}{ Distance to all seamounts } \\
\cline { 2 - 7 } & $\begin{array}{l}\text { Deviance } \\
\text { explained }\end{array}$ & $\begin{array}{l}\text { Approximate } \\
\text { significance }\end{array}$ & $\begin{array}{l}\text { Deviance } \\
\text { explained }\end{array}$ & $\begin{array}{l}\text { Approximate } \\
\text { significance }\end{array}$ & $\begin{array}{l}\text { Deviance } \\
\text { explained }\end{array}$ & $\begin{array}{l}\text { Approximate } \\
\text { significance }\end{array}$ \\
\hline $\begin{array}{l}\text { Mean residence time } \\
\text { model }\end{array}$ & $17.7 \%$ & $\begin{array}{l}\mathrm{Edf}=1.96, \\
\mathrm{~F}=57.8, \\
\mathrm{p}=<2 \mathrm{e}-16 * * *\end{array}$ & $13.0 \%$ & $\begin{array}{l}\mathrm{Edf}=1.93, \\
\mathrm{~F}=44.1, \\
\mathrm{p}=<2 \mathrm{e}-16 * * *\end{array}$ & $7.7 \%$ & $\begin{array}{l}\mathrm{Edf}=1.88, \\
\mathrm{~F}=27, \\
\mathrm{p}=2.5 \mathrm{e}-11 * * *\end{array}$ \\
\hline $\begin{array}{l}\text { Mean maximum } \\
\text { dive depth model }\end{array}$ & $3.5 \%$ & $\begin{array}{l}\mathrm{Edf}=1.93, \\
\mathrm{~F}=10.2, \\
\mathrm{p}=6.8 \mathrm{e}-05 * * *\end{array}$ & $3.2 \%$ & $\begin{array}{l}\mathrm{Edf}=1.95, \\
\mathrm{~F}=8.15, \\
\mathrm{p}=0.0004 * * *\end{array}$ & $0.5 \%$ & $\begin{array}{l}\mathrm{Edf}=1.67, \\
\mathrm{~F}=0.79, \\
\mathrm{p}=0.4\end{array}$ \\
\hline
\end{tabular}

Table 3. Summary of the Generalized Additive Models of mean maximum dive depths and mean residence time in relation to distance to seamounts.

over the Walters Shoal seamount, south of Madagascar ${ }^{65,66}\left(33^{\circ} \mathrm{S}\right)$. Although neither feeding nor defecation has ever been observed at the surface during offshore surveys in New Caledonia (C. Garrigue, pers. obs.), potential prey of the Euphausiid family has been found in these waters all year round ${ }^{67}$ and could provide opportunistic feeding opportunities. Interestingly, a small fraction of the micronekton biomass collected in New Caledonian offshore waters included Euphausia mucronata ${ }^{67}$, a krill species known to play a key role in the Humboldt Current System food chain, where it is consumed by fin whales ${ }^{68}$. In addition, in this study deep dives predominantly occurred during the day, a diel pattern that would be expected from feeding humpback whales following the vertical micronekton migration ${ }^{48,69}$. Finally, deep dives were predominantly observed over the seafloor ridges of 

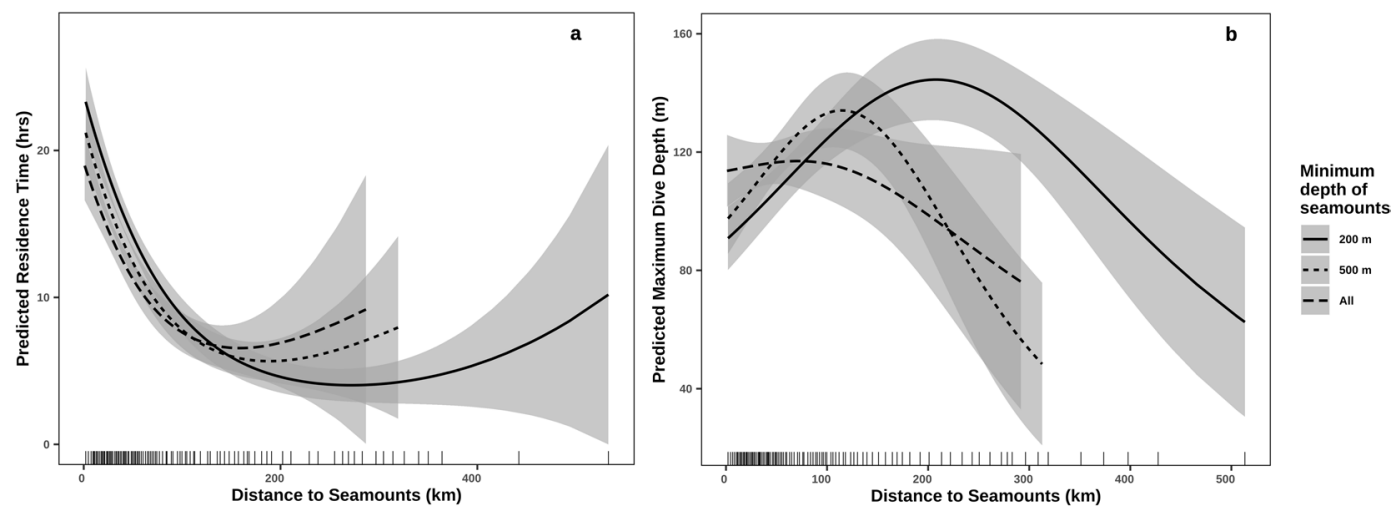

Figure 6. GAM predictions of horizontal and vertical movement of humpback whales in pelagic environment in response to the distance to seamounts. (a) Predicted Residence Time (hrs) from 18 CRW-interpolated tracks. (b) Predicted maximum dive depth $(\mathrm{m})$. Rug plots illustrate the percentile distribution of the modelled distances to seamounts shallower than $200 \mathrm{~m}$. The shaded ribbons represent approximate $95 \%$ confidence intervals.

the Coral Sea, but their relation to potentially enriched seamount waters was unclear. The low precision of the ARGOS positions ( $>50 \mathrm{~km}$ for "B" class ${ }^{70}$; composing $74 \%$ of the filtered positions in this study), and the relatively low frequency of data transmission (1 filtered position every 5.8 hours on average) impaired an accurate positioning of dive events with respect to small seamount features that extend over less than a dozen kilometres. Analysing diving behaviour at a finer spatial scale would help investigate the feeding hypothesis, as seamount slopes are often found to trigger primary productivity ${ }^{1,3,4,71}$, and could constitute opportunistic feeding spots for humpback whales in wintering latitudes.

Most survey effort to describe cetacean distribution and habitats is biased towards coastal waters ${ }^{72}$. In this study, implantable satellite tags allowed to investigate the use of pelagic waters by humpback whales during the breeding season, and confirmed the importance of shallow seamount habitat ${ }^{11}$, regardless of sex or breeding status of individuals. Indeed, several of the whales tagged in offshore waters (Antigonia or Orne bank) never stopped near a reef or a coast (seven out of 12) during the duration of tracking and remained in pelagic waters. Seamounts and banks that most attracted humpback whales included: Antigonia, Capel, Ellet, Kelso, Orne, and Torch (Fig. 1b,c). These seabed features have in common a relatively shallow depth at their summit (10 to $60 \mathrm{~m})$, surrounding seabed of 1,500 to 2,000 $\mathrm{m}$ deep, and guyot shapes with flat summits of a surface ranging from 17 $\mathrm{km}^{2}$ (Ellet) to $1,800 \mathrm{~km}^{2}$ (Capel ${ }^{73}$ ). Humpback whales have been tracked during the breeding season over similar offshore features, such as Penguin Bank, in Hawaii ${ }^{39,74}$ or La Pérouse seamount in the western Indian Ocean ${ }^{12}$. Given their low latitude and/or proximity of these seamounts to known coastal breeding grounds, breeding activities were speculated ${ }^{12}$. In New Caledonia, in situ visual surveys conducted over the southeastern seamount region have confirmed that humpback whales display behaviours typically observed in breeding grounds: intense singing activity, competitive behaviour and nursing females ${ }^{14,55}$. Yet, it is intriguing to note that whales, including mothers with a calf, would prefer these unsheltered locations instead of selecting nearby coasts and lagoons to congregate $^{14}$. Perhaps there are multiple benefits to these offshore seamounts.

What could be the benefits of pelagic seamount habitats for humpback whales? First, seamounts can represent landmarks in the open ocean. Both the shallow seabed feature itself, its geomagnetic signature ${ }^{54}$ and the peculiar turbulences that it triggers ${ }^{1}$ are likely to be detected by humpback whales. In this sense, seamounts are accessible and detectable areas for social aggregations during the breeding season. Second, it is possible that seamounts also act as "singing stages" for male humpback whales. These areas could be acoustically more suitable for singing males because they may be quieter than the surrounding pelagic environment and provide better sound propagation toward the open water ${ }^{75}$. As songs are likely to play a role in the spatial aggregation of individuals ${ }^{76,77}$, seamounts visited by great numbers of humpback whales could be acoustically attractive.

Humpback whales demonstrated localized and regional movements during the breeding season. A strong connectivity was observed at a relatively small scale among breeding aggregations of southeastern New Caledonia. Indeed, several whales repeatedly moved between breeding spots separated by 100 to $200 \mathrm{~km}$. However, the extensive longitudinal movements $(>1500 \mathrm{~km}$ ) observed from east to west of the Coral Sea further question the scale at which the humpback whale may move during the breeding season. Longitudinal movements were characterized by transit-like parameters, typically observed during migration: low residence time, high swimming speeds and oriented travelling ${ }^{10,11,36-38}$. Two males moved between the well-known breeding grounds of southeastern New Caledonia, and the presumed breeding grounds of Capel and Kelso, located at a distance of about $850 \mathrm{~km}$. Using the Lord Howe seamount chain as a stepping stone, they crossed the Coral Sea to reach the East Australian coast south of the E1 Great Barrier Reef breeding grounds ${ }^{30}$. Whether these animals were seeking mating opportunities over the Australian coast is unknown as the southerly limits to the East Australian breeding grounds are now thought to extend beyond the Great Barrier Reef ${ }^{78}$. So far, photo and genetic identifications have shown few resights between the New Caledonian breeding sub-stock E2 and the Australian migratory corridor supposed to be used by the breeding stock E ${ }^{25,79}$. However, Valsecchi et al.$^{80}$ suggested that some exchanges could 
result from differential migratory routes for males and females, specifically from extensive longitudinal movements of males during the breeding season. Further investigation into sex-specific movement dynamics in the region is warranted to understand these exchanges and the spatial scale at which the humpback whale mating system is organized. Nonetheless, extensive connectivity between aggregation sites within wintering latitudes challenges the longstanding view of humpback whale migration as a simple north-south migration with a single "final destination".

\section{Conclusion}

Satellite tag derived horizontal and vertical movements of humpback whales in the western South Pacific demonstrate that offshore shallow seamounts and banks play an important role in the spatially structured distribution of these whales during the breeding season. Several hypotheses are proposed to explain the unique diving behaviour and affinity for seamounts that were observed in pelagic waters. A deeper understanding of these offshore space use patterns has conservation implications at multiple scales. First, humpback whale population connectivity and dynamics could be reinterpreted in the light of this more comprehensive assessment of suitable nearshore and offshore breeding season habitats. Indeed, the intense use of pelagic waters located far from the coasts has consequences for estimating the structure of the endangered humpback whale breeding population of Oceania. Second, the intense use of a formerly overlooked habitat changes the understanding of exposure rates to threats for humpback whales during the breeding season. Third, the presence of an emblematic and endangered megafauna species over the seamounts of the western South Pacific has implications for the conservation of these vulnerable marine ecosystems ${ }^{81}$. Within the Natural Park of the Coral Sea, many seamounts are considered to be highly sensitive ecosystems $\mathrm{s}^{73}$ with exceptional levels of biodiversity and endemism ${ }^{82}$. The present study therefore supports the potential for humpback whales to play the role of umbrella species of conservation to the benefit of seamount ecosystems in the western South Pacific.

\section{Methods}

Satellite tag deployment. A total of 18 SPLASH10 satellite tags (Wildlife Computers, Redmond, WA 98052, USA) were deployed between 2016 and 2018 in New Caledonia (Table 1). Tags were deployed in two offshore shallow areas (Antigonia seamount, $\mathrm{n}=8$, and Orne bank, $\mathrm{n}=4$ ) and one remote coral reef complex (the Chesterfield-Bellona archipelago, $n=6$ ), in the Natural Park of the Coral Sea (Fig. 1a). Tags were implanted on adult whales, a few dozen centimetres forward of the dorsal fin, using a modified pneumatic line-thrower (ARTS, Restech) set to a minimum pressure of $10 \mathrm{bars}^{83}$. Technical details about the tag deployments are presented in Supplementary Table S4. Tagged whales were photographed using digital cameras Canon 40D and 50D equipped with $70 \times 300 \mathrm{~mm}$ or $100 \times 200 \mathrm{~mm}$ lenses with magnifier 1.4 . Tissue samples were collected with a crossbow with a specially adapted bolt ${ }^{84}$. Genomic DNA was extracted from these biopsy samples to identify sex ${ }^{85}$ and individuals ${ }^{86}$. After comparison with the New Caledonian humpback whale catalogs, photo-identification and genotyping allowed individual identification of tagged whales. Tagging and biopsy sampling were approved by the review board of the Department of Maritime Affairs under the government of New Caledonia (permits \#20161391/GNC, \#2017-1107/GNC and \#2018-923/GNC). Fieldwork was carried out in accordance with the relevant guidelines and regulations.

Marking the boundaries of the breeding region. The analysis of the tracking dataset was limited to a study region assumed to host mating, calving, nursing and early migration. It has been argued that breeding ground extents are restricted by water temperature rather than latitude. Rasmussen et al..$^{87}$ found that breeding grounds from both hemispheres were included in an average SST range of $21.1^{\circ} \mathrm{C}$ to $28.3^{\circ} \mathrm{C}$. Following this assessment, the climatology of austral winter SST was calculated for the region, using monthly remotely sensed SST products acquired for the months of July to October, from 2003 to 2014 with a spatial resolution of $1 \mathrm{~km}$ (MURSST, https://podaac.jpl.nasa.gov/dataset/MUR-JPL-L4-GLOB-v4.1). The average isotherm at $21^{\circ} \mathrm{C}$ was calculated to delineate the southern boundary of the breeding study region (Fig. 1a, Table 1).

Filtering and modelling satellite tracks. Data processing and statistical analysis were performed with $\mathrm{R}$ (version 3.4.4 ${ }^{88}$ ). ARGOS locations were filtered to remove invalid locations of class $\mathrm{Z}$, locations on land and locations implying unrealistically rapid movements ( speed $>18 \mathrm{~km} / \mathrm{h}^{89}$ ). Whenever a track was interrupted for more than 72 hours, the track was considered to be constituted by several segments, subsequently projected in a Pacific-centered Mercator coordinate system and interpolated at one position every 6 hours with a Continuous-time Correlated Random Walk (CRW) model using the R crawl package version 2.1.1 ${ }^{90}$. CRW model movement as a velocity process, characterized by two parameters: $\beta$, the velocity autocorrelation, and $\sigma$, the velocity variation. Using these models, the animal's position can subsequently be predicted at any time, from the start to the end of the original track. The error on ARGOS positions was incorporated as the ellipses semi-minor and semi-major axis error, with deployment GPS positions included with ellipses logarithmic error set to 0 . The $\beta$ parameter was constrained between $[-3,4]$ bounds and was optimized using a Normal distribution prior with mean -0.15 and standard deviation 1.5. The $\sigma$ parameter was left unconstrained and was optimized from a start value of $\log (10)$.

The distances covered were calculated along the crawl-interpolated track segments, within the previously identified breeding study region. Residence time was calculated along the crawl-interpolated tracks to assess movement type. Residence time is the total amount of time spent, both backward and forward, within a virtual circle (of radius $\rho$ ) centered on a given location, provided the animal did not move out of the circle for more than a time threshold $(\tau)$. Residence time therefore provides an integrative measure of space use ${ }^{91}$ and may reveal Area Restricted Search when animals slow down and display more sinuous paths as a result of a spatially-restricted activity (e.g., resting, feeding, or interacting with conspecifics). Area Restricted Search 
behaviour is scale-dependent, a pattern that can be tested using varying radii $\rho$ in the residence calculation. Here, residence time was calculated in a radius $\rho$ of $1,5,10$ or $20 \mathrm{~km}$ (with a time threshold $\tau$ of 12 hours) for each tagged individual. The log-transformed variance of the residence time values was averaged across individuals in order to determine the best study scale ${ }^{92}$. The $10 \mathrm{~km}$ radius was found to maximize the variance of residence time and was selected for further analysis.

Diving behaviour analysis. Diving behaviour analysis was limited to dives recorded while the humpback whales were in the breeding study region initially identified. For every dive event greater than 11 meters in depth and $1 \mathrm{~min}$ in duration, the SPLASH10 tags recorded three parameters: dive depth (maximum depth reached during dive, in meters), dive duration (in minutes) and dive shape. Dive depth is recorded by SPLASH10 tags as an interval (mean $=0.76 \mathrm{~m} \pm$ s.d. 1.27) from which the median depth value was extracted. On very rare occasions $(0.08 \%$ of dives), the wet/dry sensor of the tag may not have detected the surfacing event following a dive, resulting in aberrant values of dive duration $(\mathrm{max}=62 \mathrm{~min})$. Based on the distribution of outliers, dives $>30 \mathrm{~min}$ were filtered out. Dive depth and duration were analysed at the tagged population scale, with all tagged individuals pooled together to describe the overall vertical movement characteristics within the breeding region. Based on the relation between dive depth and duration, dives were categorized into two classes: deep dives $>80 \mathrm{~m}$, and shallow dives between 11 and $80 \mathrm{~m}$. Dive depths and durations were compared between males, females, and females with a calf, using one-way repeated measures ANOVA (i.e. within subject effect) with a rank transformation. Finally, dive shapes were used to infer behavioural modes after they were classified into three categories depending on the time spent at the bottom of the dive (i.e. below $80 \%$ of the maximum dive depth reached for a given dive): $50 \%$ of the dive duration for square-shaped dives, $20-50 \%$ for U-shaped dives, and less than $20 \%$ for $\mathrm{V}$-shaped dives. Tags were also set up to record dive profiles during a period of $24 \mathrm{hrs}$, every 7 days (in 2016) or every 3 days (in 2017 and 2018). Dive profiles record the whale's depth at a frequency of 75 s, which allowed a finer analysis of humpback whale behaviour at depth.

Seamount effect on movement. The geographic positions of dives were estimated using the CRW models from each track segment. The crwPredict function from the $\mathrm{R} c r a w l$ package predicted dive position based on the time at which the dive occurred. Preliminary analysis showed that the positional error associated with predicted dive positions was positively correlated with the time elapsed between the dive and the most recent ARGOS filtered position recorded by the tag (longitude error: Pearson's $\mathrm{r}=0.71, \mathrm{t}=89.2 \mathrm{df}=7,984, \mathrm{p}<2.2 \mathrm{e}-16$; latitude error: Pearson's $\mathrm{r}=0.76, \mathrm{t}=104.8, \mathrm{df}=7,984, \mathrm{p}<2.2 \mathrm{e}-16$ ). In order to remove potentially mispositioned dive events, all dives recorded more than 6 hours away from an ARGOS position were removed from further analysis. Track and dive positions occurring in "sheltered" waters of the East Australian coast, the New Caledonian lagoons and the Chesterfield-Bellona plateaus were excluded to focus on humpback whale movements in pelagic waters (Supplementary Fig. S5). Dive depths in pelagic waters were compared between night and day time (using a 6 a.m./6 p.m. cut-off), using a one-way repeated measures ANOVA (i.e. within subject effect) with a rank transformation.

Pelagic movement characteristics were averaged over $10 \mathrm{~km}$ resolution grids. Residence time was averaged per grid cell for each tagged whale, then individual residence time grids were averaged together. The maximum dive depth was calculated per grid cell for each tagged whale, then individual dive grids were averaged together. Gridded residence time and maximum dive depth were modelled as a function of distance to the closest seamount using Generalized Additive Models ( $m g c v$ R package, version 1.8-23, GAM ${ }^{93}$ ). The positions and depths of seamounts were obtained from a Pacific database ${ }^{94}$. Seamount depths were validated within the New Caledonian economic exclusive zone using local bathymetric charts at $500 \mathrm{~m}$ resolution ${ }^{95}$ (whenever the local charts indicated shallower summit depths than the Pacific charts, the former values were used). As seamount summit depth has been identified as an important factor of attraction for cetaceans $s^{6,8}$, distance to seamounts was calculated in three ways: distance to seamounts of all depths, distance to seamounts shallower than $500 \mathrm{~m}$, and distance to seamounts shallower than $200 \mathrm{~m}$. Both the mean residence time and mean maximum dive depth were modelled as Gaussian response variables with a log link function. The smoothed effect of distance to seamounts was optimized by Restrictive Maximum likelihood and cubic smoothing splines with basis size limited to 3 to prevent overfitting ${ }^{96}$. The performance of models was assessed by the proportion of deviance explained ${ }^{97}$.

Received: 23 October 2019; Accepted: 3 March 2020;

Published online: 17 March 2020

\section{References}

1. Rogers, A. D. The Biology of Seamounts: 25 Years on. Adv. Mar. Biol. 79, 137-224 (2018).

2. Yesson, C., Clark, M. R., Taylor, M. L. \& Rogers, A. D. The global distribution of seamounts based on 30 arc seconds bathymetry data. Deep. Res. Part I Oceanogr. Res. Pap. 58, 442-453 (2011).

3. Pitcher, T. J. et al. Seamounts: ecology, fisheries and conservation. (Oxford, UK: Blackwell Publishing Ltd., 2007).

4. Morato, T., Hoyle, S. D., Allain, V. \& Nicol, S. J. Seamounts are hotspots of pelagic biodiversity in the open ocean. Proc. Natl. Acad. Sci. 107, 9707-9711 (2010).

5. Bouchet, P. J., Meeuwig, J. J., Salgado Kent, C. P., Letessier, T. B. \& Jenner, C. K. Topographic determinants of mobile vertebrate predator hotspots: Current knowledge and future directions. Biol. Rev. 90, 699-728 (2015).

6. Morato, T. et al. Evidence of a seamount effect on aggregating visitors. Mar. Ecol. Prog. Ser. 357, 23-32 (2008)

7. Johnston, D. W. et al. Temporal patterns in the acoustic signals of beaked whales at Cross Seamount. Biol. Lett. 4, 208-211 (2008).

8. Hann, C. H., Smith, T. D. \& Torres, L. G. A sperm whale’s perspective: The importance of seasonality and seamount depth. Mar. Mammal Sci. 32, 1470-1481 (2016).

9. Torres, L. G. et al. From exploitation to conservation: habitat models using whaling data predict ditribution patterns and threat exposure of an endangered whale. Divers. Distrib. 19, 1138-1152 (2013). 
10. Kennedy, A. S. et al. Local and migratory movements of humpback whales (Megaptera novaeangliae) satellite-tracked in the North Atlantic Ocean. Can. J. Zool. 92, 8-17 (2014).

11. Garrigue, C., Clapham, P. J., Geyer, Y., Kennedy, A. S. \& Zerbini, A. N. Satellite tracking reveals novel migratory patterns and the importance of seamounts for endangered South Pacific Humpback Whales. R. Soc. Open Sci. 2, 150489 (2015).

12. Dulau, V. et al. Continuous movement behavior of humpback whales during the breeding season in the southwest Indian Ocean: on the road again! Mov. Ecol. 5, 11 (2017).

13. Garrigue, C., Zerbini, A. N., Geyer, Y. \& Clapham, P. Movements of satellite-monitored humpback whales from New Caledonia Movements of satellite-monitored humpback whales from New Caledonia. J. Mammal. 91, 109-115 (2010).

14. Derville, S., Torres, L. G. \& Garrigue, C. Social segregation of humpback whales in contrasted coastal and oceanic breeding habitats. J. Mammal. 99, 41-54 (2018).

15. Derville, S., Torres, L. G., Iovan, C. \& Garrigue, C. Finding the right fit: Comparative cetacean distribution models using multiple data sources and statistical approaches. Divers. Distrib. 24, 1657-1673 (2018).

16. Bortolotto, G. A., Danilewicz, D., Hammond, P. S., Thomas, L. \& Zerbini, A. N. Whale distribution in a breeding area: spatial models of habitat use and abundance of western South Atlantic humpback whales. Mar. Ecol. Prog. Ser. 585, 213-227 (2017).

17. Cartwright, R. et al. Between a Rock and a Hard Place: Habitat Selection in Female-Calf Humpback Whale (Megaptera novaeangliae) Pairs on the Hawaiian Breeding Grounds. Plos One 7, e38004 (2012).

18. Smith, J. et al. Identification of humpback whale breeding and calving habitat in the Great Barrier Reef. Mar. Ecol. Prog. Ser. 447, 259-272 (2012).

19. Trudelle, L. et al. First insights on spatial and temporal distribution patterns of humpback whales in the breeding ground at Sainte Marie Channel, Madagascar. African J. Mar. Sci. 40, 75-86 (2018).

20. Guidino, C., Llapapasca, M. A., Silva, S., Alcorta, B. \& Pacheco, A. S. Patterns of spatial and temporal distribution of humpback whales at the southern limit of the Southeast Pacific breeding area. Plos One 9, e112627 (2014).

21. Lindsay, R. et al. Characterising essential breeding habitat for whales informs the development of large-scale Marine Protected Areas in the South Pacific. Mar. Ecol. Prog. Ser. 548, 263-275 (2016).

22. Derville, S. et al. Whales in warming water: Assessing breeding habitat diversity and adaptability in Oceania's changing climate. Glob. Chang. Biol. 25, 1466-1481 (2019).

23. Childerhouse, S. et al. Megaptera novaeangliae Oceania subpopulation. The IUCN Red List of Threatened Species 2008: e.T132832A3463914, https://doi.org/10.2305/IUCN.UK.2008.RLTS.T132832A3463914.en (2008).

24. Garland, E. C. et al. Population structure of humpback whales in the western and central South Pacific Ocean as determined by vocal exchange among populations. Conserv. Biol. 29, 1198-1207 (2015).

25. Olavarría, C. et al. Population structure of South Pacific humpback whales and the origin of the eastern Polynesian breeding grounds. Mar. Ecol. Prog. Ser. 330, 257-268 (2007).

26. Steel, D. et al. Migratory interchange of humpback whales (Megaptera novaeangliae) among breeding grounds of Oceania and connections to Antarctic feeding areas based on genotype matching. Polar Biol. 3, 1-10 (2017)

27. Garrigue, C. et al. Movement of individual humpback whales between wintering grounds of Oceania (South Pacific), 1999 to 2004. J. Cetacean Res. Manag. 3, 275-281 (2011).

28. IWC. Report of the sub-committee on other Southern Hemisphere whale stocks. J. Cetacean Res. Manag. 7, 235-244 (2005)

29. Jackson, J. A. et al. Southern Hemisphere Humpback Whale Comprehensive Assessment - A synthesis and summary: 2005-2015. Rep. to Sci. Comm. Int. Whal. Comm. SC/66a/SH3, 1-38 (2015).

30. Paterson, R. \& Paterson, P. A study of the past and present status of humpback whales in east Australian waters. Biol. Conserv. 29, 321-343 (1984)

31. Bejder, L. et al. Low energy expenditure and resting behaviour of humpback whale mother-calf pairs highlights conservation importance of sheltered breeding areas. Sci. Rep. 9, 771 (2019).

32. Hamilton, P. K., Stone, G. S. \& Martin, S. M. Note on a deep humpback whale (Megaptera novaeangliae) dive near Bermuda. Bull. Mar. Sci. 61, 491-494 (1997).

33. Baird, R. W., Ligon, A. D. \& Hooker, S. K. Sub-surface and night-time behavior of humpback whales off Maui, Hawaii: a preliminary report. Report prepared under Contract \# 40ABNC050729 from the Hawaiian Islands Humpback Whale National Marine Sanctuary, Kihei, HI, to the Hawaii Wildlife Fund, Paia, HI. 1-19 (2000).

34. Herman, E. Y. K. et al. When Whales Collide: Crittercam Offers Insight into the Competitive Behavior of Humpback Whales on Their Hawaiian Wintering Grounds. Mar. Technol. Soc. J. 41, 35-43 (2007).

35. Videsen, S. K. A., Bejder, L., Johnson, M. \& Madsen, P. T. High suckling rates and acoustic crypsis of humpback whale neonates maximise potential for mother-calf energy transfer. Funct. Ecol. 31, 1561-1573 (2017).

36. Andrews-Goff, V. et al. Humpback whale migrations to Antarctic summer foraging grounds through the southwest Pacific Ocean. Sci. Rep. 8, 12333 (2018).

37. Riekkola, L. et al. Application of a multi-disciplinary approach to reveal population structure and Southern Ocean feeding grounds of humpback whales. Ecol. Indic. 89, 455-465 (2018).

38. Zerbini, A. N. et al. Migration and summer destinations of humpback whales (Megaptera novaeangliae) in the western South Atlantic Ocean. J. Cetacean Res. Manag. 3, 113-118 (2011).

39. Mate, B., Mesecar, R. \& Lagerquist, B. The evolution of satellite-monitored radio tags for large whales: One laboratory's experience. Deep. Res. Part II Top. Stud. Oceanogr. 54, 224-247 (2007).

40. Félix, F. \& Guzmán, H. M. Satellite tracking and sighting data analyses of Southeast Pacific humpback whales (Megaptera novaeangliae): Is the migratory route coastal or oceanic? Aquat. Mamm. 40, 329-340 (2014).

41. Gales, N. et al. Satellite tracking of Australian humpback (Megaptera novaeangliae) nd pygmy blue whales (Balaenoptera musculus brevicauda). Sci. Comm. Int. Whal. Comm. SC/62/SH21, 1-9 (2010).

42. Hazen, E. L. et al. Fine-scale prey aggregations and foraging ecology of humpback whales Megaptera novaeangliae. Mar. Ecol. Prog. Ser. 395, 75-89 (2009).

43. Tyson, R. B., Friedlaender, A. S., Ware, C., Stimpert, A. K. \& Nowacek, D. P. Synchronous mother and calf foraging behaviour in humpback whales Megaptera novaeangliae: insights from multi-sensor suction cup tags. Mar. Ecol. Prog. Ser. 457, 209-220 (2012).

44. Goldbogen, J. A. et al. Foraging behavior of humpback whales: kinematic and respiratory patterns suggest a high cost for a lunge. $J$. Exp. Biol. 211, 3712-3719 (2008).

45. Heide-Jorgensen, M. P. \& Laidre, K. L. Autumn space-use patterns of humpback whales (Megaptera novaeangliae) in West Greenland. J. Cetacean Res. Manag. 9, 121-126 (2007).

46. Ware, C., Friedlaender, A. S. \& Nowacek, D. P. Shallow and Deep Lunge Feeding of Humpback Whales in Fjords of the West Antarctic Peninsula. Mar. Mammal Sci. 27, 587-605 (2011).

47. Dietz, R., Teilmann, J., Heide-Jørgensen, M. P. \& Jensen, M. V. Satellite tracking of Humpback whales in West Greenland. NERI Technical Report (2002).

48. Friedlaender, A. S., Tyson, R. B., Stimpert, A. K., Read, A. J. \& Nowacek, D. P. Extreme diel variation in the feeding behavior of humpback whales along the western Antarctic Peninsula during autumn. Mar. Ecol. Prog. Ser. 494, 281-289 (2013).

49. Dolphin, W. F. Prey densities and foraging of humpback whales, Megaptera novaeangliae. Experientia 43, 468-471 (1987).

50. Henderson, E. E., Aschettino, J., Deakos, M., Alongi, G. \& Leota, T. Satellite Tracking of Migrating Humpback Whales in Hawai'i. Technical report 3106 Systems Center Pacific, San Diego, CA, 1-38 (2018). 
51. Van Haren, H. Humpback whale migration affected by internal wave surfing and mixing? Response to Garrigue al. 2015, 1-4 (2015).

52. Torres, L. G. A sense of scale: Foraging cetaceans' use of scale-dependent multimodal sensory systems. Mar. Mammal Sci. 33, $1170-1193$ (2017).

53. Norris, K. Some observations on the migration and orientation of marine mammals. in Animal orientation and navigation (ed. Storm, R. M.) 101-125 (Oregon State University Press, Corvallis, OR, 1967).

54. Horton, T. W. et al. Route Fidelity during Marine Megafauna Migration. Front. Mar. Sci. 4, 1-21 (2017).

55. Garrigue, C. et al. Humpback whale offshore breeding grounds in the South Pacific: unravelling the network. 22th Biennial Conference on the Biology of Marine Mammals, Halifax, Canada (2017).

56. Goldbogen, J. A. et al. How Baleen Whales Feed: The Biomechanics of Engulfment and Filtration. Ann. Rev. Mar. Sci. 9, 367-386 (2017).

57. Croll, D. A., Acevedo-Gutiérrez, A., Tershy, B. R. \& Urbán-Ramírez, J. The diving behavior of blue and fin whales: Is dive duration shorter than expected based on oxygen stores? Comp. Biochem. Physiol. - A Mol. Integr. Physiol. 129, 797-809 (2001).

58. Chittleborough, R. G. Dynamics of two populations of the humpback whale, Megaptera novaeangliae (Borowski). Mar. Freshw. Res. 16, 33-128 (1965).

59. Dawbin, W. H. The seasonal migration of humpback whales. in Whales, dolphins, and porpoises (ed. Norris, K. S.) 145-170 (Berkeley and Los Angeles, CA: University of California Press, 1966).

60. Baraff, L. S., Clapham, P. J., Mattila, D. K. \& Bowman, R. S. Feeding behaviour of a humpback whale in low-latitude waters. Mar. Mammal Sci. 7, 197-202 (1991).

61. De Sá Alves, L. C. P., Andriolo, A., Zerbini, A. N., Pizzorno, J. L. A. \& Clapham, P. J. Record of feeding by humpback whales (Megaptera novaeangliae) in tropical waters off Brazil. Mar. Mammal Sci. 25, 416-419 (2009).

62. Danilewicz, D., Tavares, M., Moreno, I. B., Ott, P. H. \& Trigo, C. C. Evidence of feeding by the humpback whale (Megaptera novaeangliae) in mid-latitude waters of the western South Atlantic. Mar. Biodivers. Rec. 2, e88 (2009).

63. Gendron, D. \& Urban, J. Evidence of Feeding By Humpback Whales Megaptera Novaeangliae in the Baja California Breeding Ground, Mexico. Mar. Mammal Sci. 9, 76-81 (1993).

64. Lagerquist, B. A., Mate, B. R., Ortega-Ortiz, J. G., Winsor, M. \& Urbán-Ramirez, J. Migratory movements and surfacing rates of humpback whales (Megaptera novaeangliae) satellite tagged at Socorro Island, Mexico. Mar. Mammal Sci. 24, 815-830 (2008).

65. Cerchio, S. et al. Satellite telemetry of humpback whales off Madagascar reveals insights on breeding behavior and long-range movements within the southwest Indian Ocean. Mar. Ecol. Prog. Ser. 562, 193-209 (2016).

66. Trudelle, L. et al. Influence of environmental parameters on movements and habitat utilization of humpback whales in the Madagascar breeding ground. R. Soc. Open Sci. 3, 160616 (2016).

67. Menkes, C. E. et al. Seasonal oceanography from physics to micronekton in the south-west pacific. Deep. Res. Part II Top. Stud. Oceanogr. 113, 125-144 (2015).

68. Pérez, M. J. et al. Fin Whales (Balaenoptera physalus) feeding on Euphausia mucronata in nearshore waters off north-central chile. Aquat. Mamm. 32, 109-113 (2006).

69. Friedlaender, A. S. et al. Diel changes in humpback whale Megaptera novaeangliae feeding behavior in response to sand lance Ammodytes spp. behavior and distribution. Mar. Ecol. Prog. Ser. 395, 91-100 (2009).

70. Nicholls, D. G., Robertson, C. J. \& Murray, M. D. Measuring accuracy and precision for CLS: Argos satellite telemetry locations. Notornis 54, 137-157 (2007).

71. Cascão, I. et al. Persistent Enhancement of Micronekton Backscatter at the Summits of Seamounts in the Azores. Front. Mar. Sci. 4, 1-15 (2017).

72. Kaschner, K., Quick, N. J., Jewell, R., Williams, R. \& Harris, C. M. Global Coverage of Cetacean Line-Transect Surveys: Status Quo, Data Gaps and Future Challenges. Plos One 7, e44075 (2012).

73. Gardes, L. et al. Analyse stratégique de l'Espace maritime de la Nouvelle-Calédonie. Agence des aires marines protégées et Gouvernement de la Nouvelle-Calédonie, Nouméa. 1-395 (2014).

74. Mate, B. R., Glsiner, R. \& Mobley, J. Local and migratory movements of Hawaiian humpback whales tracked by satellite telemetry. Can. J. Zool. 76, 863-868 (1998).

75. Frankel, A. S. \& Clark, C. W. Results of low-frequency playback of M-sequence noise to humpback whales, Megaptera novaeangliae, in Hawaii. Can. J. Zool. 76, 521-535 (1998).

76. Clapham, P. J. \& Zerbini, A. N. Are social aggregation and temporary immigration driving high rates of increase in some Southern Hemisphere humpback whale populations? Mar. Biol. 162, 625-634 (2015).

77. Herman, L. M. The multiple functions of male song within the humpback whale (Megaptera novaeangliae) mating system: Review, evaluation, and synthesis. Biol. Rev. 92, 1795-1818 (2017).

78. Torre-Williams, L., Martinez, E., Meynecke, J. O., Reinke, J. \& Stockin, K. A. Presence of newborn humpback whale (Megaptera novaeangliae) calves in Gold Coast Bay, Australia. Mar. Freshw. Behav. Physiol. 52, 199-216 (2019).

79. Garrigue, C. et al. First assessment of interchange of humpback whales between Oceania and the east coast of Australia. J. Cetacean Res. Manag. Special Is, 269-274 (2011).

80. Valsecchi, E., Corkeron, P., Galli, P., Sherwin, W. \& Bertorelle, G. Genetic evidence for sex-specific migratory behaviour in western South Pacific humpback whales. Mar. Ecol. Prog. Ser. 398, 275-286 (2010).

81. Watling, L. \& Auster, P. J. Seamounts on the High Seas Should Be Managed as Vulnerable Marine Ecosystems. Front. Mar. Sci. 4, 1-4 (2017).

82. Richer de Forges, B., Koslow, J. A. \& Poore, G. C. B. Diversity and endemism of the benthic seamount megafauna in the southwest Pacific. Nature 405, 944-947 (2000).

83. Heide-Jorgensen, M. P., Kleivane, L., Oien, N., Laidre, K. L. \& Jensen, M. V. A new technique for deploying satellite transmitters on baleen whales: Tracking a blue whale (Balaenoptera musculus) in the North Atlantic. Mar. Mammal Sci. 17, 949-954 (2001).

84. Lambertsen, R. H., Baker, C. S., Weinrich, M. \& Modi, W. S. An improved whale biopsy system designed for multidisciplinary research. in Non destructive biomarkers in vertebrates (eds. Fossi, C. \& Leonzio, C.) 219-244 (Lewis Publishers: London, 1994).

85. Gilson, A. \& Syvanen, M. Deer gender determination by polymerase chain reaction: validation study and application to tissues, bloodstains and hair forensic samples from California. Calif. Fish Game 84, 59-69 (1998).

86. Garrigue, C., Dodemont, R., Steel, D. \& Baker, C. S. Organismal and 'gametic' capture-recapture using microsatellite genotyping confirm low abundance and reproductive autonomy of humpback whales on the wintering grounds of New Caledonia. Mar. Ecol. Prog. Ser. 274, 251-262 (2004).

87. Rasmussen, K. et al. Southern Hemisphere humpback whales wintering off Central America: insights from water temperature into the longest mammalian migration. Biol. Lett. 3, 302-5 (2007).

88. R Core Team. R: A language and environment for statistical computing. (R Foundation for Statistical Computing, Vienna, Austria, 2016).

89. Zerbini, A. N. et al. Space use patterns of the endangered North Pacific right whale Eubalaena japonica in the Bering Sea. Mar. Ecol. Prog. Ser. 532, 269-281 (2015).

90. Johnson, D., London, J., Lea, M. A. \& Durban, J. Continuous-time correlated random walk model for animal telemetry data. Ecology 89, 1208-1215 (2008).

91. Barraquand, F. \& Benhamou, S. Animal movements in heterogeneous landscapes: identifying profitable places and homogeneous movements bouts. Ecology 89, 3336-3348 (2008). 
92. Fauchald, P. \& Tveraa, T. Using First-Passage Time in the Analysis of Area-Restricted Abd Habitat Selection. Ecology 84, 282-288 (2003).

93. Hastie, T. J. \& Tibshirani, R. J. Generalized Additive Models, volume 43 of Monographs on Statistics and Applied Probability. (Chapman and Hall/CRC, 1990).

94. Allain, V. et al. Enhanced seamount location database for the western and central Pacific Ocean: Screening and cross-checking of 20 existing datasets. Deep. Res. Part I Oceanogr. Res. Pap. 55, 1035-1047 (2008).

95. DTSI. Atlas bathymétrique de Nouvelle-Calédonie. Portail de l'information géographique de Nouvelle-Calédonie, http://www. geoportal.gouv.nc. Accessed February 2016, 2016).

96. Wood, S. N. Generalized additive models: an introduction with R (2nd ed.). (New York, NY: CRC Press, 2017).

97. Guisan, A. \& Zimmermann, N. E. Predictive habitat distribution models in ecology. Ecol. Modell. 135, 147-186 (2000).

\section{Acknowledgements}

We thank all the people who contributed to field work, specifically Rémi Dodémont, Véronique Pérard, and Mike Williamson, as well as the Amborella and Alis crews. We thank Claire Daisy Bonneville (Opération Cétacés), Laurent Millet (Institute of Research for Development) and Debbie Steel (Marine Mammal Institute, Oregon State University, USA) for genetic analysis. Funding and logistical help was provided by the World Wildlife Fund France, the New Caledonian Government, and the French Ministère de la Transition Ecologique et Solidaire. We especially thank the New Caledonian Government for granting access to the Amborella ship. We thank the two anonymous reviewers for their suggestions to improve the quality of the manuscript. S.D. is particularly thankful to the Herman family and the Society for Marine Mammalogy for the Louis M. Herman Research Scholarship.

\section{Author contributions}

S.D., C.G. and M.O. collected the data; S.D. and C.G. conceived the ideas and designed the methodology; S.D., C.G., A.Z. and L.T. analysed the data; S.D. led the writing.

\section{Competing interests}

The authors declare no competing interests.

\section{Additional information}

Supplementary information is available for this paper at https://doi.org/10.1038/s41598-020-61771-z.

Correspondence and requests for materials should be addressed to S.D.

Reprints and permissions information is available at www.nature.com/reprints.

Publisher's note Springer Nature remains neutral with regard to jurisdictional claims in published maps and institutional affiliations.

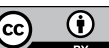

Open Access This article is licensed under a Creative Commons Attribution 4.0 International License, which permits use, sharing, adaptation, distribution and reproduction in any medium or format, as long as you give appropriate credit to the original author(s) and the source, provide a link to the Creative Commons license, and indicate if changes were made. The images or other third party material in this article are included in the article's Creative Commons license, unless indicated otherwise in a credit line to the material. If material is not included in the article's Creative Commons license and your intended use is not permitted by statutory regulation or exceeds the permitted use, you will need to obtain permission directly from the copyright holder. To view a copy of this license, visit http://creativecommons.org/licenses/by/4.0/.

(C) The Author(s) 2020 